\title{
Participation as Post-Fordist Politics: Demos, New Labour, and Science Policy
}

\author{
Charles Thorpe
}

Published online: 20 November 2010

(C) The Author(s) 2010. This article is published with open access at Springerlink.com

\begin{abstract}
In recent years, British science policy has seen a significant shift 'from deficit to dialogue' in conceptualizing the relationship between science and the public. Academics in the interdisciplinary field of Science and Technology Studies (STS) have been influential as advocates of the new public engagement agenda. However, this participatory agenda has deeper roots in the political ideology of the Third Way. A framing of participation as a politics suited to post-Fordist conditions was put forward in the magazine Marxism Today in the late 1980s, developed in the Demos thinktank in the 1990s, and influenced policy of the New Labour government. The encouragement of public participation and deliberation in relation to science and technology has been part of a broader implementation of participatory mechanisms under New Labour. This participatory program has been explicitly oriented toward producing forms of social consciousness and activity seen as essential to a viable knowledge economy and consumer society. STS arguments for public engagement in science have gained influence insofar as they have intersected with the Third Way politics of post-Fordism.
\end{abstract}

Keywords Participation · Engagement · Post-Fordism · Knowledge economy · New Labour

\section{Introduction}

Over the last decade, there has been a significant shift in the way in which the relationship between science and the public is understood and handled in British science policy. This well-documented shift is summed up in the slogan "from deficit

C. Thorpe $(\bowtie)$

Department of Sociology, University of California, San Diego, 9500 Gilman Drive, mail code 0533, La Jolla, CA 92093-0533, USA

e-mail: cthorpe@ucsd.edu 
to dialogue" (Irwin and Michael 2003, 47-55; Gregory and Lock 2008). The notion of the 'public understanding of science' that gained currency in the wake of the Royal Society's 1985 Bodmer Report entailed a one-way transfer of information from officially recognised science to the public. In contrast, a more reciprocal dialogic relationship was called for influentially in the 2000 'Science and Society' report by the House of Lords Select Committee on Science and Technology. This dialogic approach was put into practice in the early summer of 2003, when the government sponsored a series of public debates on genetically modified (GM) crops and food under the title 'GM Nation?' (Horlick-Jones et al. 2007). In 2004, the Office of Science and Technology established the Sciencewise program to promote dialogic public engagement with emerging or potentially controversial science and technology fields such as stem cell research and nanotechnology (Thorpe and Gregory 2010).

Britain has not been alone in exploring participatory initiatives. Sabine Maasen and Peter Weingart write that "[t]he 'democratization of expertise' is the order of the day in national governments and supra-national bodies such as the EU" (Maasen and Weingart 2005, 2). Denmark led the way in developing consensus conferences (Dryzek and Tucker 2008; Jensen 2005; Joss 1999; Levidow 1998, 218). Citizen juries have been used in Germany and the USA (Joss 1999, 291; Dunkerley and Glasner 1998, 182) and Germany has seen experiments with participatory technology assessment in relation to agricultural biotechnology (Levidow 1998, 217). The democratization of expertise through public participation in science and technology has also recently been promoted at the level of the European Union (Abels 2002). While comparative study of these developments is important (see for example Jasanoff 2005; Murphy and Levidow 2006), this paper seeks to understand in national political context why these new forms emerged in science policy in the UK. Whereas Danish social democracy has a longstanding tradition of active inclusion of interest organizations (Dryzek and Tucker 2008, 866), the new participatory forums that have been promoted in Britain over the last 10 years contrast with past patterns of elitist and often exclusionary governance in the UK (Dryzek et al. 2003). Despite, or even because of, this contrast with existing political culture, the forms of public engagement instituted in Britain have been, Sheila Jasanoff has said, "remarkably innovative" (Jasanoff 2005, 286). In the course of the last decade, Britain has come to be seen as being "at the forefront" in its pursuit of 'upstream engagement' in relation to emerging technologies such as nanotechnology (Joly and Kaufmann 2008, 226).

The shift toward 'dialogue' and 'engagement' took place against the background of a series of policy crises and public controversies, including the BSE crisis of the early to mid-1990s, the controversy over genetically modified foods a few years later, the foot and mouth disease outbreak of 2001, and public disquiet over claimed links between the MMR vaccine and autism. All these controversies seemed to demonstrate a breakdown in public trust in official pronouncements about issues involving science (Jasanoff 2005, 282). The idea that the relationship between science and the public needed to be reformed also gained intellectual support from sociologically-oriented academics in the interdisciplinary field of Science and Technology Studies (STS), who criticized technocratic approaches to risk and 
argued that scientific knowledge was uncertain, context-dependent, value-laden, and contestable. STS scholars argued that opening up the political and epistemic assumptions of research and technological programs for scrutiny and debate would produce a more democratic, reflexive, and 'socially robust' science and policy (Irwin 1995; Wynne 1992, 1996; Nowotny et al. 2001). These arguments influenced the pivotal 2000 report by the House of Lords Select Committee (Irwin and Michael 2003, 55). ${ }^{1}$

How were these arguments for dialogic participation in science able to gain traction in policy networks and government? Part of the explanation is elite anxiety about the crisis of legitimacy of science in the wake of BSE and later controversies. But these crises could conceivably have called forth quite different responses, for example focusing on tightening regulation and reasserting technocratic control. The appeal of arguments for participation also owed to the particular ideological orientation of the New Labour government. This paper draws attention to this political dimension of science policy, which has largely been neglected in STS. I will show that the case for new modes of public participation was an element of Third Way political thought that had influenced the development of New Labour. ${ }^{2}$ The Third Way was a new style of centre-left politics closely associated with Tony Blair's leadership of the Labour Party and Prime Ministership, and influenced by the writings of the sociologist Anthony Giddens and the London thinktank Demos. The degree of receptivity of science policy under New Labour toward participatory ideas from STS has to do with the way in which public participation was already established as a value within the Third Way, especially as formulated by Demos.

In the Third Way conception of participation, expanding the scope for public involvement was a response to the economic conditions of post-Fordism, the new economic formation characterized by flexible specialization in the organization of production, new computer and communication technologies, and the shift in advanced economies from the production of material goods to a growing emphasis on knowledge work and services. Third Way thinkers suggested that expanded participation was made possible by these new social and economic conditions and was also necessary for fostering the kind of active and creative citizens, knowledge workers, and consumers who would be the drivers of post-Fordist economic growth. In the 1990s, the rubric of post-Fordism was increasingly replaced by 'the knowledge economy,' but the core idea remained that of an economy oriented toward services and knowledge production, and new modes of flexibility both in the workplace and in social relationships and lifestyles.

Demos was an important site for the theorization of post-Fordism and the knowledge economy on the centre-left in the 1990s. The thinktank was founded in 1993 by Martin Jacques, the former editor of Marxism Today, and Geoff Mulgan, a Marxism Today contributor. It also drew in other Marxism Today collaborators,

\footnotetext{
${ }^{1}$ John Durant and Brian Wynne were the main specialist advisors to the committee, and other academics in STS and science communication gave evidence, including Martin Bauer, Steve Fuller, Alan Irwin, Steve Miller, and Jon Turney (Select Committee on Science and Technology, House of Lords, 2000, Appendices 1 and 2).

${ }^{2}$ New Labour as the context for participative approaches in science policy has been discussed in Gregory and Lock (2008 esp. 1257-1258) and Thorpe and Gregory (2010 esp. 282-285).
} 
most notably Charles Leadbeater. Marxism Today was the theoretical journal of the Communist Party of Great Britain (CPGB), but also functioned in the 1980s as the primary intellectual organ of the British left and was very influential in moderate, liberal-left and modernizing circles within the Labour Party. Jacques argues that it was "easily the most influential political magazine in Britain between 1978 and 1991" (Jacques 2006). Its termination in 1991 was a result of the folding of the CPGB in November of that year in response to the demise of the Soviet Union.

In the 1990s, Demos combined the post-Fordist argument for a modernized left with a broader Third Way political agenda that influenced the development of New Labour (Cockett 1997; Harris 2006). The notion that late modern society required a new kind of active, participatory democratic politics was axiomatic in Demos thinking in the 1990s. Much as had Marxism Today, Demos ascribed to postFordism, or what was increasingly referred to as the 'knowledge economy,' all kinds of liberating and popular democratic attributes. The idea of an inherent connection between post-Fordism and democratization was at the core of Demos thinking.

Demos intellectuals had a direct impact on policy in the early years of the Blair government. Geoff Mulgan became director of the Government's Strategy Unit and head of policy in the Prime Minister's office. Charles Leadbeater has been particularly important as a promoter of the idea of the knowledge economy, in particular with his 1999 book, Living on Thin Air. In 1998 the DTI, then under Peter Mandelson, commissioned Leadbeater to draft the White Paper Our Competitive Future: Building the Knowledge Driven Economy (DTI 1998a). The British Third Way project was very much influenced by an ideology of innovation that glamorized technology and the knowledge economy and that presented these economic developments as having liberating corollaries in the cultural and political sphere. Giddens writes that "In the early 1990s it was still unusual to speak of the emergence of the knowledge economy and many were sceptical... [But] Blair and Brown were convinced early on, and much of Labour's economic and social policy follows from this conviction" (Giddens 2008, xii).

Giddens' 1998 book, The Third Way, was important as an intellectual systematization and defense of this political orientation and he advised Blair in the early period of New Labour government (Boynton 1997; Mann 1999). Giddens shared with Marxism Today and Demos the basic idea that a new politics 'beyond left and right' (Giddens 1994) was a necessary response to social transformations such as the rise of globalization and the knowledge economy. The overlap in thinking between Giddens and Demos is suggested by Giddens' acknowledgment that The Third Way "grew out of a series of informal evening discussion meetings" between himself, Mulgan, and Ian Hargreaves (New Statesman editor and Chair of the Demos Board of Trustees) (Giddens 1998, ix). ${ }^{3}$

The combination of participation and the knowledge economy in Third Way thinking was the ideological terrain that provided a congenial environment for the entry of ideas from STS into science policy under New Labour. Demos has recently been important in advocating 'upstream' public engagement in science policy,

\footnotetext{
${ }^{3}$ For Hargreaves' Demos writings, see for example Hargreaves and Christie eds. 1998.
} 
publishing a series of reports on this topic in collaboration with STS academics (Wilsdon and Willis 2004; Wilsdon et al. 2005; Kearnes et al. 2006; Stilgoe et al. 2008). The thinktank has also carried out a series of public dialogues on nanotechnology, with funding from Sciencewise, and has created forums for discussion between STS researchers, politicians and civil servants, representatives of business, and NGOs such as Greenpeace (Stilgoe 2007; Thorpe and Gregory 2010, 293-294). Demos is not a homogeneous group, and involves, for the most part, different people today than in the 1990s. Yet, there are important thematic continuities which characterize the thinktank's general orientation and are reflected in its approach to science policy: the conceptualization of innovation as a broad social process; a view of the high skills knowledge and creative economy as the source of global competitiveness and cultural vibrancy; an image of the knowledge economy as being entwined with personal freedom and political democratization; an emphasis on networks as key features of the knowledge economy; and a critique of bureaucracy in favor of partnerships across the public and private sectors.

Analyses of post-Fordism and the knowledge economy by thinkers associated with Marxism Today and Demos set the stage both for New Labour interest in participatory forms of governance and for the entry into the policy field of STS arguments for public participation in science and technology. The links drawn by Demos thinkers between participation and post-Fordism or the knowledge economy are significant for understanding the mode in which participation has been adopted within British policy. The notion of a high-value knowledge economy as a way to compete on the global market has been central to the British government's economic strategy and particularly to the departments in which science policy has been housed, the Department of Trade and Industry (DTI), and its successors the Department for Innovation, Universities and Skills (DIUS) and the Department for Business Innovation and Skills (BIS). The British government has conceptualized public participation in science as one element within a broader policy agenda of shaping Britain as a knowledge economy. Science policy White Papers and government reports present participation as being supportive of innovation and commercialized science. The formulation of participation as a form of post-Fordist politics has resulted in its subsumption within the dominant agenda of ensuring Britain's competitiveness as a knowledge economy. This paper traces how the emergence of public participation as a strand of British science policy was influenced by arguments in Marxism Today and Demos for participation as a mode of politics suited to social and economic conditions of post-Fordism.

\section{Marxism Today: Thatcherism and New Times}

The term 'Thatcherism' was coined within the pages of Marxism Today and a key line of inquiry in the magazine concerned explicating Thatcherism as a political, social and more broadly cultural phenomenon of right-wing hegemony. Jacques and Stuart Hall argued that while Thatcherism was in many ways deeply authoritarian and backward-looking, it also tapped into forms of consciousness that were distinctively new. Thatcher's program resonated with a new culture of individualism, 
while the left was associated with forms of collectivism that had become widely viewed as anachronistic (Hall and Jacques 1983a; Hall 1983). Hall and Jacques argued in Gramscian terms that it was up to the left to develop a counter-hegemonic project. The left would not escape marginality or inexorable movement to the right unless it could itself latch onto and articulate the new social forces that Thatcher had succeeded in mobilizing (Hall and Jacques 1983a, 14-16). In order to be able to meld a progressive political orientation with the new individualism, the left had to abandon centralist and bureaucratic tendencies and instead embrace "the mobilization of democratic power at the popular level" (Hall 1983, 33).

The coherent project of Marxism Today under the editorship of Jacques was to analyze the social roots of rightwing hegemony and to construct a modernized left politics. This project matured into the concept of 'New Times,' first articulated in a special issue in 1988. 'New Times' located the culture of individualism underpinning Thatcherism in the economic and social transformations of post-Fordism, and sought to analyse post-Fordism as a cultural and political phenomenon. Fordism was underpinned by a group of social and political settlements that had unraveled (Manifesto for New Times 1990, 25-27). New settlements were in the process of being constructed for a post-Fordist society. The hope was that the analysis of New Times would help to "prise Thatcherism and that world apart" and insert into the political terrain a post-Fordist left capable of constructing a new hegemony (Hall and Jacques 1990a, 15). New Times analysis therefore paid a lot of attention to the liberating and progressive potential in post-Fordist developments: flexibility, breaking down of hierarchy, proliferation of subcultures, individual autonomy, and irreverence for tradition. Rejecting nostalgia for old working-class mass movements, Marxism Today exuded enthusiasm for late modernity, conveyed by its glossy and stylish layout and sharp journalistic eye for the latest pop-cultural trends. A common theme was choice and cultural diversity, afforded by new technologies such as Satellite TV (Manifesto for New Times 1990, 23, 34), and the proliferation of consumer brands and commodities of "Benetton Britain" (Murray 1990).

Leadbeater went beyond the other Marxism Today thinkers in arguing that the left needed not only to adapt to the cultural dimensions of post-Fordism but also to develop an economic strategy that articulated with these new forces. In a 1987 Fabian Society Tract titled The Politics of Prosperity, he urged the left to come to terms with capitalist economic competition and to abandon its attachment to public ownership and centralized planning. Facing up to post-Fordism meant that the left had to accept the need for "flexible working practices," private ownership, decentralised management, the market, and "profitability as an important measure of efficiency" (Leadbeater 1987, 11, 14). It was essential, Leadbeater declared in a pamphlet a year later, to develop a "progressive economic modernisation in contrast to the Thatcher Government's reactionary economic modernisation" (Leadbeater 1988 b, 4. Emphases in original). Leadbeater suggested that what had been taken to be contradictory goals defining left and right, for example equality versus efficiency, were false choices. These goals were now entirely reconcilable because of the social characteristics of post-Fordism. The economy was currently going through a transition into a new epoch. The 1930s saw the shift from coal-based technologies of the nineteenth century to oil and electricity based economies of the later twentieth 
century. The 1990s were witnessing a further shift into the "microelectronics and information" technologies of the twenty-first century (Leadbeater 1987, 21; see also Leadbeater 1988b, 1). Leadbeater argued that these technological and economic transformations carried with them the potential for progressive social change. Social and economic modernisation would be mutually sustaining if Britain retooled itself economically and culturally for post-Fordism, creating access to training for highly skilled employment, fostering individual choice, and institutional openness.

In the 1988 Marxism Today special issue on 'New Times,' Leadbeater made the case for what he called "Power to the Person" (Leadbeater 1988a). He argued that the new individualism of the 1980s demanded, and made possible, a new kind of active political involvement of individuals in society. Individualist aspirations for "autonomy, choice, decentralisation, [and] greater responsibility" could go beyond the Thatcherite focus on market choice and be expressed by the left in political and democratic terms (Leadbeater 1988a, 17). Leadbeater urged the left "to develop a new agenda for... democratisation of the state, and the devolution of state power to autonomous collective bodies, independent of the state." Collective action could be accomplished through a combination of the state, the market, and voluntary organisations. Rather than state provision, public action could operate through the oversight of private corporations by "[l] ocal regulatory bodies" addressing, for example, environmental concerns (Leadbeater 1988a, 18-19). Leadbeater's analysis was important for articulating the contours of a new politics for New Times, in which consumerist individualism would be extended and transformed into a "democratic individualism" (Leadbeater 1988a, 19).

There are many continuities between the New Times analysis and New Labour. For one thing, there is the sheer emphasis on newness and an accompanying valorization of the new over the old (Dillow 2007, 13; Finlayson 2003, 66). " New, new, new', Tony Blair told a meeting of European socialist leaders in a characteristic outburst, shortly after entering office, "everything is new'" (Marquand 1999, 226; see also Dillow 2007, 14). In his foreword to Our Competitive Future, he echoed this language: "The modern world is swept by change. New technologies emerge constantly, new markets are opening up. There are new competitors but also great new opportunities" (DTI 1998a, 5). An enthusiasm for the liberating tendencies of consumerism and new technologies pervades both New Times and New Labour discourse. As political theorist Alan Finlayson points out, both Marxism Today and New Labour based their politics on a sociological appraisal of current conditions and treated these sociological conditions as setting the parameters of political possibility (Finlayson 2003, 119-124).

The sociological category of the 'modern' underpinned both New Times and the emerging philosophy of the Third Way and New Labour (Morrison 2004, 171). In an article for Marxism Today in 1991, Blair echoed the language of New Times. He wrote, "The notion of a modern view of society as the driving force behind the freedom of the individual is in truth the implicit governing philosophy of today's Labour Party" (Blair 1991, 34). ${ }^{4}$ Blair's 1998 Fabian Society pamphlet, The Third Way, explored the conditions for 'modernising' left-of-centre politics in terms that

\footnotetext{
${ }^{4}$ He was, at that time, shadow employment spokesperson.
} 
resonated with the themes of post-Fordism. A "modernised social democracy," he argued, must be "flexible, innovative and forward-looking" (Blair 1998: 1; see also Finlayson 2000, 185). Blair echoed Marxism Today's criticisms of the traditional left as being rooted in a Fordist paradigm, arguing that social democracy was "inflexible...[and] too inefficient and low quality in its provision of public services" (Blair 1998, 5). The Thatcher government had engaged in "necessary acts of modernisation" (Blair 1998, 5). Blair's analysis was shot through with post-Fordist themes such as "Technological advance and the rise of skills and information as key drivers of employment and new industries" (Blair 1998, 6). Crucially, Blair followed Marxism Today in presenting post-Fordist trends as potentially liberating, connecting the new economy with a new culture of individualism and a new politics of individual responsibility: "A dynamic knowledge-based economy founded on individual empowerment and opportunity, where governments enable, not command" (Blair 1998, 7).

However, it is overly facile to regard New Times as a blueprint for New Labour. The Gramscian strategies advocated by Hall did not entail an accommodation with post-Fordist conditions, but, rather, a much more active attempt to construct a new cultural politics within these. In a final 1998 special issue of Marxism Today, Hall and other Gramscians took New Labour to task for simply accommodating themselves to Thatcherite individualism rather than creatively constructing new social alliances to support a genuinely left agenda (Finalyson 2003, 121; Gilbert 2000, 223-224; Hall 1998). But Finlayson points out that alongside the Gramscian tendency, the New Times project also incorporated a technological and economic determinist outlook which tended to present post-Fordist conditions as themselves generating or even necessitating a particular political response (Finalyson 2003, 123).

The greatest influence of Marxism Today on New Labour derived from the magazine's technological futurist orientation (Finlayson 2003, 123). The key representative of this outlook was Leadbeater, the "[1] eading Marxist enthusiast of the knowledge economy" (Finlayson 2003, 121). Leadbeater articulated a "vanguardist futurism" that characterized what Finlayson calls the "Demos tendency" within Marxism Today (Finlayson 2003, 124). The cleavage between the Demos tendency and the Gramscians such as Hall was clear in the 1998 special issue on the meaning of New Labour. Hall condemned New Labour for failing to achieve a creative counter-hegemonic project, while Mulgan (by then an advisor in 10 Downing Street) excoriated critics such as Hall and Eric Hobsbawm for refusing to recognize the practical responsibilities of government (Hall 1998; Mulgan 1998).

\section{Demos: Lean Democracy and Knowledge Capitalism}

The techno-futurist tendency of Marxism Today continued within Demos in the 1990s. Leadbeater, who became an associate of Demos and authored numerous Demos reports, was particularly important in developing and linking two strands earlier articulated in the context of 'New Times': post-Fordism and democratization. As he put it in Living on Thin Air, "The goal of becoming a knowledge-driven society... is radical and emancipatory" (Leadbeater 1999, 16). 
Consistent with Leadbeater's analysis, Demos has tended to couch democratization in techno-futurist terms. Enthusiasm for technology as a basis for democratization was a prominent theme in a 1994 issue of Demos Quarterly, with articles on "electrifying democracy" including optimistic visions of the promise of cable TV for decentralized "electronic town meetings" and "tele-voting" (Adonis and Mulgan 1994, 3; Becker 1994; Bartle 1994). New communications technology promised a move beyond mass media that would facilitate the shift from mass party politics to more decentralized forms of participation (Adonis and Mulgan 1994, 17).

In an article titled "Lean Democracy and the Leadership Vacuum," Leadbeater and Mulgan advocated "a shift towards direct democracy, offering citizens a multiplicity of channels to influence political decision making" (Leadbeater and Mulgan 1994, 47). Terming this program "lean democracy," they drew an explicit parallel with post-Fordist forms of "lean organization" in the private sector. Lean organizations are characterized by "flexibility and team work." They draw upon high skills, "waste little time, energy, skills and materials. They move fast and innovate" (Leadbeater and Mulgan 1994, 50). All this contrasted with the existing political system: politicians "are at best semiskilled" and "the output of the political system is often of low quality" (Leadbeater and Mulgan 1994, 52)."[L]ean factories" operate according to "just in time production schedules" whereas "the political system works to a just-get-by schedule" (Leadbeater and Mulgan 1994, 51-52). The rapid feedback between consumer preference and production facilitated by post-Fordist flexible production methods and information technologies provided a model for a more direct relationship between citizen preference and policy, bypassing the need for representation. Leadbeater and Mulgan wrote:

Manufacturers and retailers operating just-in-time production systems have developed hugely sophisticated computer systems to track consumer preferences in real time and translate them into production. The political system captures preferences occasionally; the private sector has learned to track them constantly (Leadbeater and Mulgan 1994, 53).

As in just-in-time production, new technologies would make possible new kinds of reflexivity. Recalling Robin Murray's Marxism Today analysis of "Benetton Britain," Leadbeater and Mulgan wrote: "Retailers have the technology to record thousands of real time changes in people's preferences" and they asserted, "There is no reason why this technology should not be applied to politics: a just-in-time democracy. The democratic possibilities of combining the television, personal computer and information superhighway have hardly been explored" (Leadbeater and Mulgan 1994, 61).

New technology would provide the means for democratization. But there was also the deterministic argument that new technologies themselves required this democratic shift. So Leadbeater and Mulgan noted the incongruity of new technologies with old fashioned mass party politics (Leadbeater and Mulgan 1994, 67). Politics needed to engage in a more complete way "with a culture that is increasingly electronic, based on computers, video and compact discs, where text, image and sound combine" (Leadbeater and Mulgan 1994, 67). In a subsequent issue of Demos Quarterly on "Liberation Technology?" focusing on the coming 
"information superhighway," Mulgan emphasized interactivity as a feature of contemporary technology and culture: "Modern generations expect to be able to respond... [They] doubt any format that is simply monologue" (Mulgan 1994, 3). Direct democratization was therefore mandated by the pace of technological change. This was a politics of 'future shock.'

Leabeater and Mulgan's discourse of direct democracy mobilized a distinctly managerial language: the need to "learn from the best practices in the corporate sector," the politician as a "[s]ervice provider", the evaluation of "performance," a “just-in-time democracy" (Leadbeater and Mulgan 1994, 57, 63, 61; see also Gilbert 2000; Dillow 2007). They couched the need for democratization in terms of the necessity of keeping up to date and maintaining efficient performance and delivery. Citizens were cast as customers. For example, Leadbeater and Mulgan complained that "Many layers of political and civil service bureaucracy separate the customers (citizens) from the producers (powerholders)" (Leadbeater and Mulgan 1994: 51). In line with this managerial framework, they asserted the end of ideology. Instead of the zero-sum conflict of left and right, there could be a "positive sum politics" (Allen 1994). Mulgan argued that Demos's proposals were geared toward "life after politics" (Mulgan 1997a, b, xviii-xix; see also Leadbeater 1999: 16). If the political task was adaptation to the knowledge economy, then ideology was indeed no longer relevant. The politician was just a manager of societal change.

\section{Governing Through Culture}

Demos inherited from Marxism Today a conviction as to the political importance of culture. Whether writing about new technologies, economic enterprise, employment, or the functions of government, the emphasis for Demos was on cultural values and practices. As Mulgan put it, "The starting point is culture" (Mulgan 1994: 3). However, this was a very different kind of cultural politics from the Gramscian style advocated by Hall. Demos's approach to culture was tightly bound up with its technofuturism: technological and economic modernization was carrying with it a tendency toward cultural modernization. Mapping onto the knowledge economy was a new culture of openness, pluralism, individual self-expression, and democratic assertiveness. It was these values that Demos thinkers such as Mulgan, Leadbeater, Perri 6, Tom Bentley, and others saw coming to the fore in Britain in the run-up to the 1997 election, and which they celebrated as representing a "British Spring." "The generations, brought up against the background of empire and traditional values," they argued, "are slowly giving way to a generation brought up with globalisation and information technologies, greater equality between men and women, and ecological awareness" (Mulgan et al. 1997, 1). For these Demos thinkers, the British public increasingly showed attachment to post-Fordist and "post-material" values of individual choice and personal freedom (Mulgan et al. 1997, 16). Demos celebrated these features of the post-Fordist public as a break from the closed, hierarchical, and class-bound cultures of Britain's past. The linking of the new economy with cultural transformation is exemplified by Leadbeater's case for making Britain the "California 
of Europe": promoting the new economy would promote an informal, entrepreneurial and creative culture, for which California in the 1990s seemed the ideal model (Leadbeater 1997b).

Demos thinkers presented cultural change both as something that followed from technological and economic developments and as something that had to be managed and actively shaped for the sake of promoting these developments. Culture was therefore a proper target for policy. Perri 6, Demos's research director, made the case for "Governing by Cultures." In contrast to the narrow "economistic view of government's powers" that dominated in the twentieth century, he argued that government could exert influence by enabling the cultural shifts that in turn supported economic change: "Creating and sustaining the cultural resources necessary to make privately based economic dynamism and social viability possible is the central task for society." The state should act as a "culture catalyst," working to build "social capital" and thereby enabling "a viable capitalist social order" (6 1995, 2, 4, 5, 8).

6 dwelt on the need for government to help foster a "high trust" culture. Britain's economic performance was hindered by the fact that it was "still a low-trust society" (6 1995, 5, 6). A key Third Way concern in the 1990s was the growing disconnect between politics and the public, witnessed by low election turnout, apathy, and distrust. For Demos this indicated the gap that had opened up between late modern culture and overly rigid old-fashioned institutions (Mulgan 1997a, b, x, xvii). In their case for 'lean democracy,' Leadbeater and Mulgan suggested that direct democratization would lead to a restoration of public trust in government. The editorial to the 'lean democracy' issue of Demos Quarterly asserted that by making politics "more transparent and responsive, more effective and more accountable" lean democracy would "restore public confidence that politicians are fit to lead society" (Demos 1994, vii).

The concern with culture and trust also followed from Demos's advocacy of decentralization. The notion of the 'network' was crucial to Demos thinking about governance, as the thinktank argued for the decentralization of public action, from Whitehall to networks of voluntary organizations and civic or social entrepreneurs (Leadbeater 1997a; Leadbeater and Goss 1998). Drawing on current sociological analysis, Leadbeater emphasized the underpinnings of the new economy in network forms such as university-industry links and innovation hubs (Leadbeater 1999, 111, 127-133, 141; see also Bevir 2005: 45, 51). Informal culture and practices seemed to be more significant than formal rules for maintaining such decentralized, network forms of organization. For Leadbeater, trust was the essential "lubricant" for the knowledge economy (Leadbeater 1999, 150). Crucially, Leadbeater recognized broad public trust in technoscientific institutions as a social condition for successful innovation. The key example was Monsanto's failure to generate public trust in GM foods. Companies like Monsanto relied on public trust which provided "their license to operate and innovate" (Leadbeater 1999, 153).

The idea of a crisis of trust, which has become so central to government concern with 'science and society,' was articulated in more general terms by Leadbeater as an aspect of the transition to "knowledge capitalism" (Leadbeater 1999, 9). Leadbeater suggested that a "wave" of social and institutional innovation needed to take place in order to make good "our trust deficit" (Leadbeater 1999, 150). 
Leadbeater recognized that neoliberal marketization had undermined traditional forms of solidarity, but saw the positive side of this in creating the free agents who could form networks and engage in innovation. He rejected the communitarian view that trust was rooted in shared values: we should promote "modern rather than traditional, open rather than closed, forms of trust" (Leadbeater 1999, 167).

The network of free agents, bound together by bonds of trust rather than hierarchical organization, was Demos's template for reconceptualizing institutions. Leadbeater's prescriptions for the welfare state, for example, involved breaking down the traditional public sector and its large organizations and mass provision and instead developing public-private partnerships linking the state with businesses and voluntary organizations and encouraging 'civic' or social entrepreneurship. These ideas drew support from the American political scientist Mark Moore's notion of "public value." Moore's book, which was taken up by Mulgan while head of the Prime Minister's Strategy Unit, was a manifesto for transforming public management away from centralized bureaucratic structures toward more flexible, decentralized and responsive relationships between "coproduce[rs]" (Moore 1995, 117-118; Wilsdon et al. 2005, 28; cf. Newman 2007, 41). In Moore's view, public sector management should be about finding "ways to engage loose networks of professions, interest groups, political associations, and the media in efforts to coproduce the managers' goals" (Moore 1995, 118). Moore drew on the example of post-Fordist modes of management (e.g. "getting close to the customer") in the private sector and he contrasted his program with the older top-down model of "scientific management" (Moore 1995, 288). Leadbeater invoked the notion of public value in Living on Thin Air as he argued for the reorganization of the public sector: "We need a welfare state that is increasingly focused on investment in social capital, to create public value and to develop people's capabilities to look after themselves" (Leadbeater 1999, 230). Leadbeater has subsequently developed the idea that the users of public services should no longer be passive recipients but, rather, actively involved in "co-production," i.e. "shaping the service they receive" (Leadbeater 2004, 59; see also Needham 2007). This argument also extended Leadbeater's Marxism Today case for a personal politics centering on individual responsibility (see also Leadbeater et al. 2008).

Demos's advocacy of participation in the 1990s was linked to its case for reshaping the social and cultural order for the knowledge economy. This meant a new institutional fluidity, including the devolution of governmental power into the social via networks of public and private institutions, voluntary associations, etc. It also meant the promotion of new forms of subjectivity, instilling and requiring the exercise of agency by citizen-consumers. Participation would help to promote this new social identity of the citizen-consumer and would foster the social and cultural conditions (especially trust) for the new decentralized practices of governance and innovation.

\section{Giddens: Democratization, Globalization and Reflexivity}

These kinds of arguments were reinforced by the sociological theory of Giddens. He shared with Demos such fundamental tenets as the idea that globalization was 
creating a more fluid society in which there was a greater emphasis on individual responsibility and that new post-materialist values were taking precedence over older class politics, so that the classic left-right split was losing its salience. This context called for greater responsiveness of government to citizens. In The Third Way, therefore, Giddens advocated "democratizing democracy” (Giddens 1998, 70):

The downward pressure of globalization introduces not only the possibility but the necessity of forms of democracy other than the orthodox voting process. Government can re-establish more direct contact with citizens, and citizens with government, through "experiments with democracy"-local direct democracy, electronic referenda, citizens' juries (Giddens 1998, 75; see also Thorpe and Gregory 2010, 283).

He suggested that forms of direct democracy could be an "enduring complement" to voting and representative government (Giddens 1998, 75).

Giddens presented such institutional reforms as necessary adaptations to sweeping social changes: globalization, but also intensifying individualism, accompanied by what Giddens called 'life politics' concerned with issues such as identity, the environment, health, sexuality, leisure, etc. (Giddens 1991; Driver and Martell 2002, 83). Life politics was an instantiation of a new reflexivity (i.e. knowledgeable self-monitoring) across all areas of social life, reflecting the decline of convention and traditional authority, and the necessity of making choices amid a proliferation of information and expertise (Giddens 1990, 109; 1991; 1994a; Finlayson 2003, 129). This critical knowledgeability of social life owed a great deal to science, but science was itself becoming subject to democratic reflexivity: "science and technology cannot stay outside democratic processes. Experts cannot be relied upon automatically to know what is good for us... they should be called upon to justify their conclusions in the face of public scrutiny" (Giddens 1998, 59).

Giddens argued that globalization gave rise to a more reflexive individual consciousness and a more skeptical public, demanding new modes of accountability and governance (Giddens 1990, 156-158). Finlayson points out that this analysis shared with the techno-futurist orientation within Marxism Today, and especially with Demos, the sense that "there is no point waging any resistance" against the objective reality of globalization (Finlayson 2003, 129). Indeed, argues Finlayson, "the more technological and futurist side of New Times, that which predominates in a think-tank like Demos, can find in Giddens' theory the ethical and ontological basis it lacks" (Finlayson 2003, 130). Giddens' sociology provided a framework for justifying policies as being mandated by objective societal conditions, especially as ways of reconciling social and political order with social change. For Giddens, sociological understanding enables political action as "the practical governance of social change" (Giddens in Cassell ed. 1993, 146-148). And Giddens has suggested that he shared with Blair this recognition of the need for politics to respond to social change: "One of the reasons I quite like being reasonably close to Tony Blair is he does, to me, take seriously that the world has changed in fundamental ways over the past 20 or 30 years" (Giddens, quoted in Mann 1999). In the Foreword to a book evaluating 10 years of New Labour, Giddens suggests that, at least in broad terms, his analysis was taken on board: "I am not suggesting that Labour's leaders would 
ever themselves have deployed such arcane terminology as 'reflexivity'... But I do believe they accepted the need to respond to these... sets of influences, and that this acceptance helps one understand much about the New Labour project" (Giddens 2008: xiii).

\section{New Labour and the Politics of Participation}

The view that political transformation was mandated by social change informed Blair's advocacy of new forms of democratic involvement, which he presented as updating citizenship in line with the new culture of consumerist individualism. In his 1991 Marxism Today article, Blair advanced democratization as a way of channeling individualism into public action, rather than individual agency just being expressed via the market (Blair 1991,33). The notion of a renewal of democracy was prominent also in Blair's 1998 Fabian Society pamphlet. Blair devoted a section to "Active Government: Partnership and Decentralisation," in which he argued enthusiastically for "experiments" with democracy, including citizen juries: "The democratic impulse needs to be strengthened by finding new ways to enable citizens to share in decision-making that affects them. For too long a false antithesis has been claimed between 'representative' and 'direct' democracy" (Blair 1998, 15).

Blair's justifications for political change bore a striking resemblance to Marxism Today's analysis of New Times. There was the same sociologism-a view of politics as adaptation to social and economic transformation. Blair described the Third Way approach as " "permanent revisionism'... based on a clear view of the changes taking place in advanced industrial societies" (Blair 1998, 4). He argued that old left politics "was an expression of old industry" and that the welfare state reflected Keynesian-Fordist relations of "secure jobs" and "relatively closed national economies." Those structures were not well suited to a "world of growing competition, external shocks and industrial and technological change" (Blair 1998, $5,8)$.

The argument was for the transformation of the state along post-Fordist lines. Government would need to "learn new skills... acting flexibly to anticipate problems and solve them" (Blair 1998, 7). Similarly to Leadbeater and Mulgan's notion of 'lean democracy,' Blair applied the terms of post-Fordism-flexibility, skills, and responsiveness-to the activities of politics and the structures of government.

Since the 1990s, 'democratization' has been presented by New Labour as a defining feature of their political program. For example, the election manifesto of 1997 promised a new approach of open and decentralized decision-making. Since then, the New Labour government has indeed implemented participatory initiatives in local government and social policy areas such as urban redevelopment, hospital governance, and public services (Pratchett 1999; Gustafsson and Driver 2005; Marinetto 2003; Dinham 2005; Chandler 2001; Rowe and Shepherd 2002; Thorpe and Gregory 2010). The July 1998 White Paper Modern Local Government: In Touch with the People (DETR 1998) set out proposals aimed at encouraging local 
authorities to establish consultation processes such as citizen juries, panels and referenda (Rao 2000, 134-145).

However, revealingly, these reforms in local government were framed in terms of the managerial post-Fordist language of efficient delivery, responsiveness, flexibility, joined-up government, best practice, and streamlining (Rao 2000, 127-130, 178-179). Social policy researcher Mike Marinetto has argued that New Labour has characterized the relationship between local government and citizens in "quasiconsumerist terms." Local authorities were required to draw up Best Value Performance Plans and distribute these to the public, who could respond via questionnaire surveys or "focus-group style public consultations" (Marinetto 2003, 116). In this way, participation has been bound up with the reconfiguration of public services in terms of consumerist values.

Participation exercises under New Labour were connected to the value of 'choice' in public services and recipients of services were recast as active 'citizenconsumers' (Clarke et al. 2007; Clarke 2005, 2007; Newman and Clarke 2009, 150). In 2004, Blair argued that in the future "service will be driven not by the government or by the manager but by the user" (Blair, quoted in Newman and Clarke 2009, 160). The participation agenda is thereby linked to an ideal of the active citizen as both consumer and co-producer. Participation unleashes this reflexive activity, but in order to do so it must create or foster these kinds of active subjects (see also Thorpe and Gregory 2010; Finlayson 2003, 194).

New Labour's implementation of participation is therefore linked to a vision of a new social order and new social subjects. In his 1987 Fabian pamphlet, Leadbeater argued that to develop a credible political strategy, the Labour party "must be strategic in a forward-looking sense. There must be some vision of what kind of society this strategy would create" (Leadbeater 1987, 3). Talk of reshaping culture and society has become pervasive in UK science policy, in which promoting the knowledge economy is presented as requiring cultural change, particularly within universities. In his foreword to Our Competitive Future, Blair wrote that "In Government, in business, in our universities and throughout society we must do much more to foster a new entrepreneurial spirit" (DTI 1998a, 5). The creation of a 'new spirit' as the task of government is an idea that has a strong affinity with Perri 6's notion that governments need to have "missions to influence cultures" and with the broader Demos idea of cultural change as a necessary accompaniment of economic change (6 et al. 1995, 1).

There is a tension in New Labour ideology between presenting policy as responding to objective social change and presenting policy as itself actively transforming society. But the two approaches are reconciled in the following way: the activity of shaping subjectivities, or governing through culture, is geared primarily toward fostering the social attributes regarded as necessary in order to successfully adapt to the objective conditions - the rise of consumerism and the knowledge economy. The task of shaping culture is to ensure the cultural and social underpinnings of the knowledge economy: an entrepreneurial spirit in institutions, and a consumerist orientation in public life. 


\section{The Knowledge Economy and Public Engagement with Science and Technology}

Initiatives toward public engagement with science and technology should be understood as an aspect of this broader Third Way movement toward 'democratization' as a strategy of governance of, and through, culture. This broader impetus toward 'participation' and 'involvement' in British political rhetoric provides the discursive and ideological context in which specific arguments for public engagement in science have gained traction. In particular, public engagement gains its policy rationale from the idea that it is a 'new politics' appropriate to the 'new economy.'

The notion that Britain needs to mobilize its science base for commercial success and competitiveness in the global market is the central idea in British science policy. The primary purpose of science policy, in this view, is to develop an "innovative knowledge economy that will enable us to compete against low-wage countries like India and China" (Sainsbury 2007, 4). Public engagement in science policy derives political legitimacy from being embedded in these discourses of postFordism and the knowledge economy (Thorpe and Gregory 2010).

The idea that innovation takes place in the context of a web of both competitive and cooperative relationships is expressed in the notion of the "innovation ecosystem" in Lord Sainsbury's The Race to the Top (2007: 23; DIUS 2008a, 11). Ensuring a benign "ecosystem" for commercializable technological innovation means shaping not only institutions, but also public attitudes and emotions. The Sciencewise (c. 2008) statement of "The Government's Approach to Public Dialogue on Science and Technology" defines the function of public engagement as follows: "Our objective is to build confidence in decision-making related to the undertaking, development and overall governance of science and technology; to build on the public's generally positive views of science" (Sciencewise 2008. Emphases added). The language of 'confidence' as it appears in science policy instantiates New Labour's governance through culture, since it involves the conceptualization of governance as involving the active shaping of social consciousness (see also Irwin and Michael 2003, 52-53; Thorpe and Gregory 2010). The 2004 DTI Five-Year program argued: "Our vision for Britain's knowledge economy means a society that is more confident about the development, governance, regulation and use of science and technology" (DTI 2004, 15). This went together with goals of employability for life replacing a job for life, and of fostering an "enterprise" culture: "Young people need to be excited about the possibilities of running their own businesses" (DTI 2004, 21). Such phrases suggest that economic strategy requires the governance of culture, constructing affective conditions such as confidence and excitement. These are subjective attributes of a population that does not resist, but instead embraces insecurity and change as desirable aspects of late modernity.

This kind of enthusiasm for change would seem to characterize the ideal consumer that the DTI referred to in its earlier pivotal White Paper on the knowledge-driven economy: "Businesses which produce such [new] products will only develop where they can gain access to leading-edge customers" (DTI 1998b, 8 ). Lord Sainsbury notes that consumers are increasingly active in the "co-creation" 
of products (Sainsbury 2007, 24). The need for a public composed of active and flexible consumers is suggested also in the recent DIUS (2008b) consultation document $A$ Vision for Science and Society: "Those who have the confidence to use devices and engage with new developments are able to drive consumer innovation" (DIUS 2008b, 7). Analysis of what drives innovation is then translated into prescription; the DIUS asserts, "We believe everyone should be a confident consumer of science and technology" (DIUS 2008b, 27).

The Vision document presents change itself as an imperative: as the "pace of scientific development accelerates, so too does the pace of change in our society... We want to ensure ... that nobody gets left behind" (DIUS 2008b, 7). Not only individuals, but also institutions must be adaptable. Theories of the knowledge economy and Third Way theories of governance assert the need to remake institutions and break down organizational boundaries, unmaking large modernist bureaucracies and instead constructing fluid networks, for example via publicprivate partnerships. There is, however, in the DIUS document, recognition that this very blurring of institutional boundaries itself gives rise to problems of distrust: "Given the close links which exist between business, government and scientists there is an increased risk of a lack of perceived independence in science." So the government's task in relation to these new networks is to remake the social conditions for legitimacy: to improve "public reassurance" and "work to improve public perception” (DIUS 2008b, 30; see also Thorpe and Gregory 2010, 287).

The university is presented as having a role not only in producing new technologies, but also in helping to foster cultural adaptation to that technological change. This is the value of participation and engagement as an academic activity. The drive toward public engagement means that it is necessary "to shift the organisational culture in Universities" so that "engaging with the public [becomes] a key part of what it is to be an academic" (DIUS 2008b, 19, 21). The transformed academic will then assist with the remaking of public subjectivities: "professionalising public engagement" will help toward "increasing excitement in science" (DIUS 2008b, 20).

The consultation document asserts: "There is no reason why the way science is conducted, governed or communicated by the private sector should be or be perceived to be any different from the public sector" (DIUS 2008b, 30). What is surprising in the sentence is the notion that science may be not only produced but also governed by the private sector. This departs from traditional notions of the difference between public and private. But it fits with New Labour's conception of governance as a process operating through networks across blurred and unstable boundaries. What holds this complex together is not structure or rules, but more diffuse conditions of culture and affect. Therein lies the significance of public engagement for the knowledge economy, as a technique for governing culture, managing affect, and producing subjectivities.

\section{Conclusion: STS, Demos, and Post-Fordist Politics}

There has been growing disquiet within STS about the limitations of the UK government and science elite's commitment to genuine democratic participation 
(Irwin and Michael 2003, 55; Wynne 2006; Irwin 2006; Lezaun and Soneryd 2007; Stirling 2008; Thorpe and Gregory 2010). Brian Wynne, an influential advocate of public engagement, has decried the policy construction of participation as a tool for enhancing public trust in science and technology. He likens the adoption of participatory language in government policy to "hitting the notes but missing the music" (Wynne 2006). My analysis suggests, however, that British science policy is in tune with the Third Way as a politics celebratory of post-Fordism and the knowledge economy. This gave rise to the conceptualization of participation as a political form suited to post-Fordist conditions, facilitating the emergence of active citizen-consumers amenable to the products and services of a knowledge economy. The science policy view that public participation fosters 'confident consumers' derives its meaning from this broader context of Third Way thought.

Demos has been an important source of advocacy for participatory ideas in British science policy and has established close links with the academic field of STS. Nonetheless, recent Demos thinking about science and technology is highly continuous with the thinktank's more longstanding framework set out earlier in this paper. A case in point is Demos's report on The Public Value of Science (2005). The report has Wynne as a coauthor and draws extensively on research from STS and on anti-technocratic arguments for participation. But it derives its title concept from the mid-1990s work of Moore that influenced Leadbeater and Mulgan (Wilsdon et al. 2005, 27-28). Here, the concept of public value provides the basis for attaching a broader socially progressive agenda to the knowledge economy. Rather than seeing the democratization of science as an obstacle to tapping the economic value of science, democratization and participation should be seen as adding value (Wilsdon et al. 2005, 59-60). This broader public value is not at odds with, but complements, and even facilitates, the pursuit of economic value.

The Demos authors specifically reject an outright opposition to the commercialization of science: "Collaboration between universities and businesses can be very positive, and there are strong economic arguments why the UK needs a lot more of it." They assert that "The question is not if we strengthen such links but how" (Wilsdon et al. 2005, 55. Emphases in original). The shift of the question from 'if' to 'how' renders a political problem into a problem of management or implementation. This way of approaching politics has been characteristic of both Demos and New Labour and is linked to the idea that we are in an age "after politics" in which polarities of left and right have been transcended (Mulgan ed., 1997b; Gilbert 2000, 229).

The notion that ideological oppositions have been suspended conditions the approach to democratization. If political questions are transformed into ones of implementation, then democratization can be seen not as unleashing conflict but as a kind of collaborative brainstorming. Democratization is understood as enabling a 'positive-sum politics' (Allen 1994), one that adds perspectives and adds value. In this way, democracy and participation can be seen as promoting innovation. Demos's output continues to be characterized by an optimistic view of the liberating potential of technology, and by the suggestion that innovation is fostered by horizontal participatory relationships and hindered by hierarchy. Leadbeater, who has continued to collaborate with Demos (for example, Leadbeater and Wilsdon 
2007), is of particular interest for the way in which his work spans the analysis of post-Fordism within Marxism Today, the 'new economy' concepts of the late 1990s period of dot-com exuberance, and today's notions of Web 2.0, open innovation, or mass innovation (Leadbeater 2008). In Leadbeater's work spanning these concepts, one can see a consistent portrait of the shift away from Fordist mass production and bureaucratic organization toward flexible production entailing a wide range of liberatory social and political outcomes: the development of a new kind of individualism, cultural pluralism and diversity, and new modes of non-hierarchical, collaborative production. Leadbeater's analysis of post-Fordism and the knowledge economy emphasizes the flexibility of new technologies and of the social forms that accompany them, and presents a picture of the decentralized and pluralistic character of contemporary innovation processes.

James Wilsdon and Rebecca Willis's 2004 Demos report on See-Through Science draws on Leadbeater's notion of "open innovation" as an argument for deepening public engagement (Wilsdon and Willis 2004, 50). Engagement, they argue, means involving the public in the innovation process, drawing on diverse social actors as sources of innovative ideas. As in Web 2.0, products are increasingly given content and value by users; hence, public engagement can become part of this process of diffuse, decentralized innovation. Where the talk of engagement as a way to produce confidence was a "defensive" way of linking "innovation and public engagement," open innovation suggests a more active and positive connection between these agendas (Wilsdon and Willis 2004, 49).

In their 2007 report on the rise of Asian knowledge economies, Leadbeater and Wilsdon suggest that "mass innovation" is vital if Britain is to compete in a context of the globalization of science (Leadbeater and Wilsdon 2007, 50). They write:

Britain needs an approach to innovation that is not just about the scientific elite, the trendy creative class or entrepreneurial superheroes but which recognises the contribution that everyone can make as consumers, citizens and creators. And this message must be cast in terms of cosmopolitan innovation: Britain as a place that is open to the world's best ideas, and which will support anyone from anywhere to put those ideas into practice (Leadbeater and Wilsdon 2007, 51).

Similarly to the Marxism Today analysis of the cultural pluralism fostered by post-Fordism and the 1997 Demos report on The British Spring, notions of democracy and cosmopolitanism are brought into association with the knowledge economy.

It was in the context of an intellectual alchemy between democracy and innovation that ingredients of STS scholarship and argument entered into British science policy discourse. Yet, the resulting mixture is not entirely consistent. Advocacy of participatory democracy, assuming the openness of technological choices, sits uneasily with Demos's longstanding framework of deterministic techno-futurism. The framework is deterministic in treating the emerging conditions of post-Fordism, the knowledge economy, and globalization as brute realities to be accepted and adapted to, rather than resisted. Similarly, New Labour has emphasized that constant innovation is an imperative of competition in the global 
economy. This is to locate science, as Dominique Pestre has put it, "outside the dialogic order" (Pestre 2008, 103. Emphasis in original). If it is necessary to keep up to date and not fall behind, then the course is already set and there would seem to be scant choice and little therefore about which to deliberate. These tensions are inherent in the Third Way framing of participation as a form of political involvement adapted to, and supportive of, a post-Fordist economy and society.

Open Access This article is distributed under the terms of the Creative Commons Attribution Noncommercial License which permits any noncommercial use, distribution, and reproduction in any medium, provided the original author(s) and source are credited.

\section{References}

6, Perri. 1995. Governing by cultures. Demos Quarterly 7: 2-8.

6, Perri et al. 1995. Missionary government. Demos Quarterly 7: 1.

Abels, Gabriele. 2002. Experts, citizens, and Eurocrats-towards a policy shift in the governance of biopolitics in the EU. European Integration online Papers (EIoP) 6(19), http://eiop.or.at/eiop/ texte/2002-019a.htm.

Adonis, Andrew, and Geoff Mulgan. 1994. Back to Greece: The scope for direct democracy. Demos Quarterly 3: 1-28.

Allen, Graham. 1994. Positive sum politics. Demos Quarterly 3: 93-94.

Bartle, Martin. 1994. Initiatives and experiments. Demos Quarterly 3: 117-124.

Becker, Theodore L. 1994. Electrifying democracy. Demos Quarterly 3: 111-116.

Bevir, Mark. 2005. New Labour: A Critique. London: Routledge.

Bewes, Timothy, and Jeremy Gilbert. 2000. Cultural Capitalism: Politics after New Labour. London: Lawrence and Wishart.

Blair, Tony. 1991. Forging a new agenda. Marxism Today, October 32-34.

Blair, Tony. 1998. The Third Way: New Politics for the New Century. London: The Fabian Society.

Boynton, Robert. 1997. The two Tonys: A profile of LSE's Anthony Giddens. The New Yorker, October 6, 66-74.

Cassell, Philip, ed. 1993. The Giddens Reader. Houndmills, Basingstoke: MacMillan.

Chandler, D. 2001. Active citizens and the therapeutic state: The role of democratic participation in local government reform. Policy and Politics 29(1): 3-14.

Clarke, John. 2005. New Labour's citizens: Activated, empowered, responsibilized, abandoned? Critical Social Policy 25(4): 447-463.

Clarke, John. 2007. 'It's not like shopping': Citizens, consumers, and the reform of public services. In Governance, Consumers and Citizens: Agency and Resistance in Contemporary Politics, eds. Mark Bevir, and Frank Trentmann, 97-118. Houndmills, Basingstoke: Palgrave MacMillan.

Clarke, John, et al. 2007. Creating Citizen-Consumers: Changing Publics and Changing Public Services. London: Sage.

Cockett, Richard. 1997. Demos's brave new words. Times Higher Education Supplement July 11, http://www.timeshighereducation.co.uk/story.asp?storyCode=159990\&sectioncode=5.

Demos, 1994. Lean democracy. Demos Quarterly 3: vii-ix.

DETR. 1998. Modern Local Government: In Touch with the People. London: HMSO.

Dillow, Chris. 2007. The End of Politics: New Labour and the Folly of Managerialism. Petersfield, Hampshire: Harriman House.

Dinham, Adam. 2005. Empowered or over-powered? The real experiences of local participation in the UK's new deal for communities. Community Development Journal 40(3): 301-312.

DIUS. 2008a. Implementing 'The Race to the Top': Lord Sainsbury's Review of Government's Science and Innovation Policies. London: HMSO.

DIUS. 2008b. A Vision for Science and Society: A Consultation on Developing a New Strategy for the $U K$. London: HMSO.

Driver, Stephen, and Luke Martell. 2002. Blair's Britain. Oxford: Polity Press. 
Dryzek, John S., et al. 2003. Green States and Social Movements: Environmentalism in the United States, United Kingdom, Germany, and Norway. Oxford: Oxford University Press.

Dryzek, John S., and Aviezer Tucker. 2008. Deliberative innovation to different effect: Consensus conferences in Denmark, France, and the United States. Public Administration Review 68(5) (September/October): 864-876.

DTI. 1998a. Our Competitive Future: Building the Knowledge Driven Economy. London: HMSO.

DTI. 1998b. Our Competitive Future: Building the Knowledge Driven Economy. The Government's Competitiveness White Paper: Analysis and Background. London: HMSO.

DTI. 2004. Five Year Programme-Creating Wealth from Knowledge. London: HMSO.

Dunkerley, David, and Peter Glasner. 1998. Empowering the public? Citizens' juries and the new genetic technologies. Critical Public Health 8(3): 181-192.

Finlayson, Alan. 2000. New Labour: The culture of government and the government of culture. In Bewes and Gilbert, 177-202.

Finlayson, Alan. 2003. Making Sense of New Labour. London: Lawrence and Wishart.

Giddens, Anthony. 1990. The Consequences of Modernity. Stanford: Stanford University Press.

Giddens, Anthony. 1991. Modernity and Self-Identity: Self and Society in a Late Modern Age. Stanford: Stanford University Press.

Giddens, Anthony. 1994a. Beyond Left and Right: The Future of Radical Politics. Stanford, CA: Stanford University Press.

Giddens, Anthony. 1994b. Living in a post-traditional society. In Ulrich Beck, Anthony Giddens, and Scott Lash, Reflexive Modernization: Politics, Tradition, Aesthetics in the Modern Social Order, 56-109. Stanford: Stanford University Press.

Giddens, Anthony. 1998. The Third Way: The Renewal of Social Democracy. Cambridge: Polity Press.

Giddens, Anthony. 2008. Foreword. In Ten Years of New Labour, eds. Matt Beech and Simon Lee, xixviii. Basingstoke: Palgrave MacMillan.

Gilbert, Jeremy. 2000. Beyond the hegemony of New Labour. In Bewes and Gilbert, 223-244.

Gregory, Jane, and Simon J. Lock. 2008. The evolution of 'public understanding of science' in the UK. Sociology Compass 2(4): 1252-1265.

Gustafsson, Ulla, and Stephen Driver. 2005. Parents, power and public participation: Sure start, an experiment in New Labour governance. Social Policy and Administration 39(5): 528-543.

Hall, Stuart. 1983. The great moving right show. In Hall and Jacques, 19-39.

Hall, Stuart, 1998. The great moving nowhere show. Marxism Today. November/December, 9-14.

Hall, Stuart, and Martin Jacques (eds.). 1983a. The Politics of Thatcherism. London: Lawrence and Wishart.

Hall, Stuart and Martin Jacques. 1983a. Introduction. In Hall and Jacques, 9-16.

Hall, Stuart, and Martin Jacques (eds.). 1990a. New Times: The Changing Face of Politics in the 1990s. London: Verso.

Hall, Stuart and Martin Jacques. 1990a. Introduction. In Hall and Jacques.

Hargreaves, Ian, and Ian Christie (eds.). 1998. Tomorrow's Politics: The Third Way and Beyond. London: Demos.

Harris, John. 2006. Blue sky thinking_Or just plain barmy? The Guardian. June 15, http://www. guardian.co.uk/politics/2006/jun/15/thinktanks.labour. Accessed June 9, 2009.

Horlick-Jones, Tom, John Walls, Gene Rowe, Nick Pidgeon, Wouter Poortinga, Graham Murdock, and Tim O'Riordan. 2007. The GM Debate: Risk, Politics, and Public Engagement. London: Routledge.

Irwin, Alan. 1995. Citizen Science: A Study of People, Expertise and Sustainable Development. London: Routledge.

Irwin, Alan. 2006. The politics of talk: Coming to terms with the 'new' scientific governance. Social Studies of Science 36(2): 299-320.

Irwin, Alan, and Mike Michael. 2003. Science, Social Theory and Public Knowledge. Maidenhead, UK: Open University Press.

Jacques, Martin. 2006. Marxism Today: Introduction by Martin Jacques (May), http://www. amielandmelburn.org.uk/collections/mt/index_frame.htm. Accessed May 22, 2009.

Jasanoff, Sheila. 2005. Designs on Nature: Science and Democracy in Europe and the United States. Princeton, NJ: Princeton University Press.

Jensen, Casper Bruun. 2005. Citizen projects and consensus-building at the Danish Board of Technology. Acta Sociologica 48(3): 221-235.

Joly, Pierre-Benoit, and Alain Kaufmann. 2008. Lost in translation? The need for "upstream engagement" with nanotechnology on trial. Science as Culture 17(3): 225-247. 
Joss, Simon. 1999. Public participation in science and technology policy-and decision-makingephemeral phenomenon or lasting change? Science and Public Policy 26(5) (October): 290-293.

Kearnes, Matthew, Phil Macnaghten, and James Wilsdon. 2006. Governing at the Nanoscale: People, Policies and Emerging Technologies. London: Demos.

Leadbeater, Charles. 1987. The Politics of Prosperity. London: Fabian Society.

Leadbeater, Charles. 1988a. Power to the person. Marxism Today. October, 14-19.

Leadbeater, Charles. 1988b. Productive and competitive economy. Policy Review. Fabian Society Discussion Paper 4 (October).

Leadbeater, Charles. 1997a. The Rise of the Social Entrepreneur. London: Demos.

Leadbeater, Charles. 1997b. Britain: The California of Europe? London: Demos.

Leadbeater, Charles. 1999. Living on Thin Air: The New Economy. New York: Viking.

Leadbeater, Charles. 2004. Personalisation through Participation. London: Demos.

Leadbeater, Charles. 2008. We-Think. London: Profile Books.

Leadbeater, Charles, and Sue Goss. 1998. Civic Entrepreneurship. London: Demos.

Leadbeater, Charles, and Geoff Mulgan. 1994. Lean democracy and the leadership vacuum. Demos Quarterly 3: 45-78.

Leadbeater, Charles, Jamie Bartlett, and Niamh Gallagher. 2008. Making it Personal. London: Demos.

Leadbeater, Charles, and James Wilsdon. 2007. The Atlas of Ideas. London: Demos.

Levidow, Les. 1998. Democratizing technology—Or technologizing democracy? Regulating agricultural biotechnology in Europe. Technology in Society 20: 211-226.

Lezaun, Javier, and Linda Soneryd. 2007. Consulting citizens: Technologies of elicitation and the mobility of publics. Public Understanding of Science 16: 279-297.

Maasen, Sabine, and Peter Weingart. 2005. What's new in science advice to politics? In Democratization of Expertise? Exploring Novel Forms of Scientific Advice in Political Decision-Making, eds. Sabine Maasen and Peter Weingart, 1-19. Dordrecht, Netherlands: Springer.

Manifesto for New Times. 1990. The New Times. In Hall and Jacques eds, 1990, 23-37. (First published June 1989).

Mann, Nyta. 1999. All aboard the Third Way. BBC Online Network (March 19), http://news.bbc.co. uk/2/hi/uk_news/politics/298465.stm. Accessed October 15, 2010.

Marinetto, M. 2003. Who wants to be an active citizen? The politics and practice of community involvement. Sociology 37(1): 103-120.

Marquand, David. 1999. The Progressive Dilemma: From Lloyd George to Blair, 2nd ed. London: Phoenix Giant.

Moore, Mark H. 1995. Creating Public Value: Strategic Management in Government. Cambridge, MA: Harvard University Press.

Morrison, David. 2004. New Labour, citizenship and the discourse of the third way. In The Third Way and Beyond, eds. Sarah Hale, Will Leggett, and Luke Martell, 167-185. Manchester: Manchester University Press.

Mulgan, Geoff. 1994. Networks for an open society. Demos Quarterly 4: 2-6.

Mulgan, Geoff. 1997a. Introduction. In ed. Mulgan, ix-xix.

Mulgan, Geoff, ed. 1997b. Life after Politics: New Ideas for the 21st Century. London: Demos.

Mulgan, Geoff. 1998. Whinge and a prayer. Marxism Today. November/December, 15-16.

Mulgan, Geoff, et al. 1997. The British Spring: A Manifesto for the Election after Next. London: Demos.

Murphy, Joseph, and Les Levidow. 2006. Governing the Transatlantic Conflict over Agricultural Biotechnology: Contending Coalitions, Trade Liberalisation and Standard Setting. London: Routledge.

Murray, Robin. 1990. Benetton Britain. In Hall and Jacques, 1990, 54-64. (Originally published in Marxism Today, November 1985).

Needham, Catherine. 2007. Realising the potential of co-production: Negotiating improvements in public services. Social Policy \& Society 7(2): 221-231.

Newman, Janet. 2007. Rethinking 'the public' in troubled times: Unsettling state, nation and the liberal public sphere. Public Policy and Administration 22(1): 27-47.

Newman, Janet, and John Clarke. 2009. Publics, Politics and Power: Remaking the Public in Public Services. London: Sage.

Nowotny, Helga, Peter Scott, and Michael Gibbons. 2001. Re-Thinking Science: Knowledge and the Public in an Age of Uncertainty. Cambridge: Polity Press.

Pestre, Dominique. 2008. Challenges for the democratic management of technoscience: Governance, participation and the political today. Science as Culture 17(2): 101-119. 
Pratchett, L. 1999. New fashions in public participation: Towards greater democracy? Parliamentary Affairs 52(4): 616-633.

Rao, Nirmala. 2000. Reviving Local Democracy: New Labour, New Politics?. Bristol: The Policy Press.

Rowe, R., and M. Shepherd. 2002. Public participation in the NHS: No closer to citizen control? Social Policy and Administration 36(3): 275-290.

Lord Sainsbury of Turville. 2007. The Race to the Top: A Review of Government's Science and Innovation Policies. London: HMSO.

Sciencewise. c. 2008. The government's approach to public dialogue on science and technology. www.sciencewise-erc.org.uk.

Select Committee on Science, Technology, House of Lords. 2000. Science and Technology-Third Report. London: HMSO.

Stilgoe, Jack. 2007. Nanodialogues: Experiments in Public Engagement with Science. London: Demos.

Stilgoe, Jack, Alan Irwin, and Kevin Jones. 2008. The Received Wisdom: Opening Up Expert Advice. London: Demos.

Stirling, Andy. 2008. 'Opening up' and 'closing down': Power, participation and pluralism in the social appraisal of technology. Science, Technology and Human Values 33(2): 262-294.

Thorpe, Charles and Jane Gregory. 2010. Producing the post-Fordist public: The political economy of public engagement with science. Science as Culture 19(3) (September): 273-301.

Wilsdon, James, and Rebecca Willis. 2004. See-Through Science: Why Public Engagement Needs to Move Upstream. London: Demos.

Wilsdon, James, Brian Wynne, and Jack Stilgoe. 2005. The Public Value of Science. London: Demos.

Wynne, Brian. 1992. Public understanding of science research: New horizons or hall of mirrors? Public Understanding of Science 1(1): 37-43.

Wynne, Brian. 1996. Misunderstood misunderstandings: Social identities and public uptake of science. In Misunderstanding Science: The Public Reconstruction of Science and Technology eds. Alan Irwin, and Brian Wynne, 19-46. Cambridge: Cambridge University Press.

Wynne, Brian. 2006. Public engagement as a means of restoring public trust in science-Hitting the notes, but missing the music? Community Genetics 9: 211-220. 